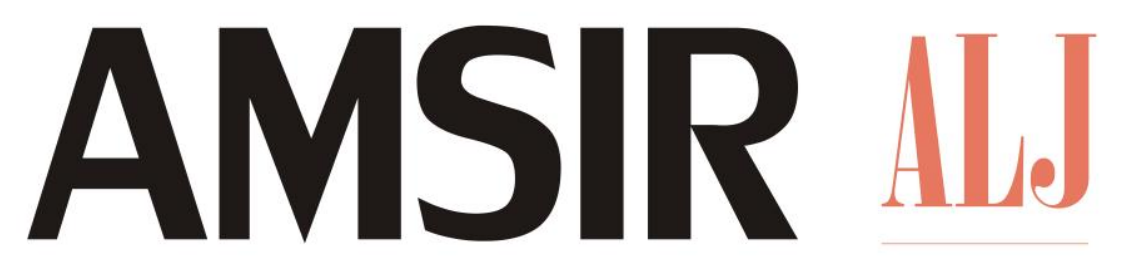

Volume 2

Issue 2

April, 2021

\title{
Potensi Penanganan Pidana Harta Benda melalui Konsep Diversi
}

\section{Abdurrifai Abdurrifai ${ }^{1}$}

\section{ARTICLE INFO}

\section{Keywords:}

Diversion, Property Crime,

Restorative Justice.

How to cite:

Abdurrifai Abdurrifai.

(2021). Potensi Penanganan

Pidana Harta Benda melalui

Konsep Diversi. Amsir Law

Journal, 2(2). 50-58.

DOI:

$10.36746 /$ alj.v2i2.33

\begin{abstract}
This study aimed at examining how and is it possible the setteling property crimes with the concept of diversion through the principle of restorative justice. This was the normative research, with the concept, historical, philosophy. Data were collected using the documentation studies and interviews. The sources of the data were analyzed by description, comparison, evaluation, and argumentation. The research results incicate that deliberation to reach consensus by involving victims, perpetrators and their families, law enforcement officials and third parties is the spirit of the concept of diversion through the principle of restorative justice. The deliberation proces between the prepetrator and the victim and/or the victim's family is carried out freely with the principle of equality and balance, so that the resulting decisions reflect justice, benefit and legal certainty. The concept of diversion through the principle of restorative justice for property crimes, has essentially been practiced customary law communities in Indonesia have long been and are still practiced, however, the Indonesian legal system or the criminal justice system has not been strictly regulated in the from of a law. The use and application and regulation are stillat a discretionary level in each law enforcement agency.
\end{abstract}

Copyright (C) 2021 ALJ. All rights reserved.

\section{Pendahuluan}

Marcus Tullius Cicero dengan adagium populernya, ubi societas ibi ius meyakinkan masyarakat Romawi, di mana ada masyarakat maka tentu pula ada hukum. Adagium ini memberi kita pengertian bahwa hukum tidak mungkin ada jikalau masyarakat tidak ada; masyarakat tidak akan tertib teratur jikalau hukum tidak hadir di situ. Sederhananya, masyarakat dan hukum tak dapat dipisahkan.

Adanya hubungan timbal balik antara hukum dan masyarakat tentu sangat memengaruhi perbuatan hukum di antara individu. Hidup yang terjalin atau terjadi karena

\footnotetext{
Ikatan Notaris Indonesia, Maros, Indonesia.Email:fai.nangatela@gmail.com
} 
adanya aktivitas interaksi manusia, baik dalam mempertahankan hidup maupun dalam memenuhi kebutuhan hidup masing-masing, terkadang menimbulkan akibat hukum yang dapat mengakibatkan kerugian baik moril maupun materil. Guna memulihkan kerugian termaksud, maka individu harus menempuh upaya hukum, baik itu upaya hukum perdata maupun pidana. Khusus di bidang keperdataan, dapat dilakukan gugatan wanprestasi dan perbuatan melawan hukum.

Dalam proses penegakan hukum di bidang keperdataan, proses wanprestasi dan perbuatan melawan hukum sangat panjang dan melelahkan. Akibatnya, sebagian pihak menempuh jalan pintas dengan melakukan upaya hukum pidana: melapor kepada aparat kepolisian setempat. Laporan dapat berupa tindak pidana penggelapan atau penipuan. Hanya saja penyelesaian masalah yang berawal dari perbuatan hukum keperdataan menjadi masalah pidana kerap ditangani sesuai aturan hukum acara pidana yang tertulis. Apabila penyidik menemukan bukti permulaan yang cukup bahwa peristiwa itu adalah peristiwa pidana dan setelah memenuhi seluruh unsur tindak pidana, maka pelakunya mesti mempertanggungjawabkan perbuatannya secara pidana sesuai yang tertulis di undangundang.

Proses penegakan hukum haruslah mengedepankan kebenaran substansial daripada kebenaran prosedural yang mengutamakan prosedur yang kadang merampas hak-hak para pencari keadilan. Pembaharuan hukum diperlukan karena laju perkembangan zaman dan perubahan pola pikir manusia yang semakin cepat berubah menyebabkan pola peraturan perundang-undangan kian tertinggal dari praktik-praktik hukum yang hidup di masyarakat.

Konsep sistem peradilan pidana (hukum pidana) kedepannya mesti memperhatikan efektivitas dan efisiensi ekonomi terkait dengan sanksi pidana dalam proses penyelesaian suatu perkara. Konsep hukum pidana yang semata-mata mengedepankan pemidanaan atau pembalasan, sudah perlahan mulai ditinggalkan dan sudah memasuki era baru atau fase baru, yaitu pembaruan sistem hukum pidana yang mengarah pada perlindungan hukum terhadap korban dengan memberikan ganti rugi dan memberi efek jera kepada pelaku. ${ }^{2}$

Dalam kaitannya dengan penegakan hukum tindak pidana terhadap harta benda, perlu dipikirkan alternatif penyelesaian masalah seperti upaya diversi dalam kasus anak. Hal ini berguna memberi perlindungan hukum kepada semua pihak terkait, yaitu korban dan pelaku dengan mengedepankan nilai keadilan, kemanfaatan, dan kepastian hukum.

Diversi saat ini menjadi salah satu sarana hukum yang dinilai sangat akomodatif terhadap kepentingan para pihak dalam melakukan penyelesaian suatu perkara pidana di luar dan saat di pengadilan. Diversi dilakukan melalui musyawarah dengan melibatkan anak dan orang tua/walinya, korban dan/atau orang tua/walinya, pembimbing kemasyarakatan dan pekerja sosial profesional berdasarkan pendekatan keadilan restoratif. ${ }^{3}$

Pada prinsipnya penerapan diversi melalui keadilan restoratif, adalah langkah strategis untuk melakukan pembaharuan hukum di bidang hukum pidana, terutama dalam terwujudnya asas sederhana, cepat, dan biaya ringan (murah), selain itu pula dapat mengurangi beban negara dalam membiayai nara pidana yang semakin besar dan daya tampung penjara atau lembaga pemasyarakatan yang melebihi kapasitas.

\footnotetext{
2 Dalam tatanan hukum pidana dikenal adanya asas ultimum remedium. Asa ini merupakan salah satu asas yang terdapat dalam hukum pidana Indonesia yang menyatakan bahwa hukum pidana hendaklah dijadikan upaya terakhir dalam hal penegakan hukum. Mertokusumo mengartikan bahwa ultimum remedium sebagai alat terakhir. Lihat Novita Sari. (2017). Penerapan Asas Ultimum Remedium dalam Penegakan Hukum Tindak Pidana Penyalahgunaan Narkotika. De Jure, 3(3): 353.

${ }^{3}$ Bruce Anzward dan Suko Widodo. (2020). Kebijakan Penerapan Diversi dalam Penyelesaian Perkara Tindak Pidana yang Dilakukan oleh Anak melalui Pendekatan Restorative Justice. Jurnal De Facto, 7(1): 38-59.
} 
Tidak semua perkara pidana harus dipidana, ada perkara-perkara tertentu yang perlu dilakukan terobosan hukum dengan menggunakan pendekatan atau konsep seperti diversi, sebagaimana halnya tindak pidana terhadap anak, mestinya untuk harta benda ${ }^{4}$ patut pula dilakukan pengujian karena pada dasarnya pidana ini bersifat personal. Hal mana sematamata bertujuan untuk mencapai keadilan yang substantif sebagaimana nilai-nilai yang telah terkristalisasi dalam Pancasila yang menjadi sumber hukum masyarakat Indonesia.

\section{Metode}

Penelitian ini menggunakan jenis penelitian hukum normatif (doktrinal). ${ }^{5}$ Didukung dengan empat pendekatan, yaitu pendekatan undang-undang (statute approach), pendekatan historis (bistorical approach) dan pendekatan filosofis (philosophy approach). Penelitian dilakukan dengan studi kepustakaan/dokumentasi kemudian dianalisis secara kualitatif berdasarkan bahan hukum primer (peraturan perundang-undangan), bahan hukum sekunder (bahan pustaka dan jurnal ilmiah), serta bahan hukum tersier (kamus hukum).

\section{Penyelesaian Tindak Pidana terhadap Harta Benda melalui Penggunaan Konsep Diversi}

\subsection{Konsep Diversi dalam Penegakan Hukum Pidana}

Pembaharuan hukum harus mewarnai struktur, substansi dan budaya hukum. Melalui sistem inilah, hukum akan dapat mencapai tujuannya yang bukan saja keadilan, kemanfaatan, dan kepastian, tetapi lebih dari itu yaitu menjunjung tinggi harkat martabat manusia dan kemanusiaan.

Pada prinsipnya penegakan hukum tindak pidana terhadap harta benda perlu penanganan yang komprehensif, jelas, dan tegas dalam rangka memberikan perlindungan kepada pihak yang dirugikan. Penanganan komprehensif yang dimaksud dalam hal ini merupakan penanganan yang keluar dari pakem atau cara-cara penegakan hukum pidana yang cenderung konvensional, prosedural, dan kaku. Penanganan komprehensif yang dimaksud dalam hal ini ialah dengan menggunakan konsep diversi.

Diversi dalam Black's Law Dictionary, a turning aside or altering the natural course or route of a thing, yang mana dapat dimaksudkan sebagai suatu tindakan yang diambil di mana tindakan tersebut berbeda atau menyimpang dari aturan pada umumnya, oleh sebab alasan tertentu. ${ }^{6}$ Dalam United Nations Standard Minimum Rules for the Administration of Juveniles Justice atau The Beijing Rules, ialah pemberian kewenangan kepada aparat penegak hukum untuk mengambil tindakan-tindakan kebijaksanaan dalam menangani atau menyelesaikan masalah pelanggar anak dengan tidak mengambil jalan formal antara lain menghentikan atau meneruskan atau melepaskan dari proses peradilan pidana atau mengembalikan atau menyerahkan kepada masyarakat dan bentuk-bentuk kegiatan pelayanan sosial lainnya. ${ }^{7}$

Prinsip utama pelaksanaan konsep diversi yaitu tindakan persuasif atau pendekatan non penal dan memberikan kesempatan kepada seseorang untuk memperbaiki kesalahan. Petugas dalam melaksanakan diversi menunjukkan pentingnya ketaatan kepada hukum dan aturan. Petugas melakukan diversi dengan cara pendekatan persuasif dan menghindari penangkapan yang menggunakan tindakan kekerasan dan pemaksaan. Ini menekankan pada upaya untuk melakukan diversi yang dilakukan aparat penegak hukum dengan cara

\footnotetext{
4 Pengecualian untuk "pencurian dengan kekerasan", "pemberatan" dan "pemerasan dengan ancaman".

${ }^{5}$ Muhammad Sabir Rahman. (2019). Fines Sanction as a Meeting Form Principles of Agreement Contracts Construction Service. Amsir Law Journal, 1(1): 17. https://doi.org/10.36746/alj.v1i1.18 .

${ }_{6}$ Marwan Effendy. (2014). Teori Hukum dari Perspektif Kebijakan, Perbandingan dan Harmonisasi Hukum Pidana. Jakarta: Referensi Centre Group, hlm. 145-146.

${ }^{7}$ R. Wiyono. (2016). Sistem Peradilan Pidana Anak di Indonesia. Jakarta: Sinar Grafika, hlm. 45-46.
} 
persuasif dan tanpa tindakan kekerasan pada saat melaksanakan penangkapan. Pada upaya komunikasi persuasif yang dibebankan pada petugas untuk menghindari tindakan kekerasan dan pemaksaan. ecara umum diversi adalah pengalihan penanganan kasus-kasus anak yang diduga telah melakukan tindak pidana dari proses formal dengan atau tanpa syarat. ${ }^{8}$

Pasal 1 angka 6 Undang-Undang Nomor 11 Tahun 2012 tentang Sistem Peradilan Pidana Anak (UU SPPA) menetapkan bahwa adanya kemungkinan untuk melakukan pengalihan penyelesaian perkara anak dari proses peradilan pidana ke proses di luar peradilan pidana. Proses ini guna mencapai peradilan berbasis musyawarah yang melibatkan pelaku, korban, keluarga pelaku/korban, dan pihak lain yang terkait untuk bersama-sama mencari penyelesaian yang adil dengan menekankan pemulihan kembali (restorasi) pada keadaan semula, dan menghindari pembalasan sebagaimana lazimnya pidana.

Menurut Levine, tujuan diversi yaitu mengeluarkan anak dari proses peradilan orang dewasa, agar anak tidak lagi diperlakukan sama dengan orang dewasa. Diversi sebagai upaya untuk melakukan tindakan persuasif atau tindakan non-penal, memberikan kesempatan kepada pelaku untuk memperbaiki kesalahannya dan bertanggung jawab, mengakui kesalahan serta menghindarkan anak dari penangkapan yang menggunakan tindakan kekerasan dan pemaksaan. ${ }^{9}$

Dalam sistem hukum Indonesia (sistem peradilan pidana), penyelesaian perkara dengan konsep diversi melalui prinsip keadilan restoratif awal mula terdapat dalam UU SPPA, sedangkan untuk tindak pidana terhadap harta benda belum diatur secara eksplisit dalam perundang-undangan (belum menjadi hukum positif dan menjadi hukum formil). Namun demikian aparat penegak hukum telah mengambil diskresi dengan menerapkannya pada tahapannya masing-masing dan dalam bentuk penyelesaian melalui mekanisme keadilan restoratif, seperti halnya pada tahapan penyidikan, dengan berdasar pada:

1) Surat Kepala Badan Reserse Kriminal Kepolisian Republik Indonesia Nomor STR/583/VIII/2012 tentang Penerapan Restorative Justice;

2) Surat Edaran Kapolri Nomor 8 Tahun 2018 tentang Penerapan Resorative Justice dalam Penyelesaian Perkara Pidana;

3) Peraturan Kepala Kepolisian Negara Republik Indonesia Nomor 6 Tahun 2019 tentang Penyidikan Tindak Pidana; dan

4) Peraturan Kejaksaan Agung Agung Republik Indonesia Nomor 15 Tahun 2020 tentang Penghentian Penuntutan Berdasarkan Keadilan Restoratif.

Penegakan hukum harus memperhatikan kaidah-kaidah dan nilai hidup yang terkandung, hidup di masyarakat dan, tidak selalu berdasarkan apa kata undang-undang, karena sejatinya inilah yang disebut hukum yang berkeadilan yang dapat memberikan keadilan dan kemanfaatan yang bermuara pada terjaganya harkat martabat manusia. Nilainilai yang hidup dalam masyarakat menurut Achmad Ali dan Wiwie Heryani bukanlah semata-mata soal hukum adat saja, melainkan juga nilai-nilai yang hidup dalam masyarakat kita di era globalisasi ini yang sudah lebih banyak ditransfer dari nilai luar yang masuk melalui teknologi canggih seperti televisi dan media komunikasi modern lain. ${ }^{10}$

\footnotetext{
${ }^{8}$ Muhammad Sidrat, et.al. (2019). Syarat Diversi pada Anak yang Berkonflik dengan Hukum dalam Konsep Pemidanaan Halu Oleo Legal Research. 1(2): 277-290.

${ }^{9}$ Edward K Morris and Curtis J. Braukmann. (1987). Behavioral Approach to Crime and Deliquency: A Handbook of Application, Research and Concepts. New York: Plenum Press, hlm. 252.

10 Achmad Ali dan Wiwie Heryani. (2013). Menjelajah Kajian Empiris terhadap Hukum. Jakarta: Kencana Prenadamedia Group, hlm. 230.
} 


\subsection{Potensi Penggunaan Konsep Diversi terhadap Tindak Pidana Harta Benda}

Penyelesaian perkara tindak pidana terhadap harta benda dengan menggunakan konsep diversi melalui pendekatan keadilan restoratif sudah dikenal dalam praktik masyarakat hukum adat. Konsep diversi pada dasarnya telah dipraktikkan oleh masyarakat Indonesia sejak dahulu, sebab pada hakikatnya merupakan nilai-nilai dasar dan telah menjadi karakter masyarakat Indonesia. Hampir semua masyarakat hukum adat di Indonesia memiliki cara masing-masing dalam menyelesaikan masalahnya tergantung adat istiadat.

Konsep dasar pendekatan restoratif berupa tindakan untuk "membangun kembali hubungan yang rusak akibat tindak pidana" telah dikenal dan dipraktikkan masyarakat hukum adat di Indonesia. Dengan perkataan lain dapat dikatakan bahwa filosofi pendekatan restoratif, memulihkan keadaan pada semula sebelum terjadinya konflik, idalah identik dengan filosofi "mengembalikan keseimbangan yang terganggu" yang terdapat dalam masyarakat hukum adat Indonesia. ${ }^{11}$

Diversi merupakan suatu konsep baru dalam sistem peradilan pidana anak di Indonesia. Diversi dan restorative justice mempunyai suatu kerangka pikir dalam upaya mencari alternatif penyelesaian terhadap kasus tindak pidana yang dilakukan tanpa hukuman pidana. ${ }^{2}$ Untuk menghindari proses peradilan dan pengalihan lebih kepada proses pelayanan sosial dan melindungi anak dari stigmatisasi peradilan yang akan mengganggu mental anak. Definisi pengalihan adalah untuk menemukan solusi dengan mengalihkan masalah yang berhubungan langsung dengan anak menuju ke luar pengadilan. $^{13}$

Penyelesaian pelanggaran adat dengan menyelesaikan sendiri secara kelompok oleh pihak-pihak yang terlibat dalam konflik, merupakan ciri diversi yang kita kenal hari ini. Tokoh adat memegang peranan penting dalam penyelesaian pelanggaran adat yang terjadi. Tokoh adat yang dilibatkan adalah mereka yang memiliki pengaruh, berwibawa, jujur, dan berintegritas serta tidak memihak. Mereka memiliki moral force sehingga para pihak (korban dan pelaku) percaya atas keputusan mereka.

Masyarakat adat Bugis, Sulawesi Selatan, dikenal penyelesaian dengan cara tudang sipulung yang dilanjutkan dengan tudang pangngadereng. Cara ini dikatakan murah karena memang tidak membutuhkan biaya dan waktu yang terlalu banyak. Syaratnya, masingmasing pihak yang terlibat konflik benar-benar memahami hakikat objek yang menjadi sumber pemicu konflik dan masing-masing pihak juga benar-benar bermaksud menciptakan perdamaian bersama. ${ }^{14}$

Kitab Latoa (ditulis oleh Mattulada) di masyarakat Bugis, mengatakan tanda kebesaran suatu negara ialah tidak ada persengketaan dalam negeri. Dijelaskan bahwa perbuatan yang menyebabkan rusaknya kesejahteraan rakyat, ialah jika orang-orang di dalam negeri bersengketa. ${ }^{15}$ Latoa memakai kata-kata tidak ada persengketaan, artinya boleh saja terjadi perselisihan tetapi kemudian ditiadakan menyelesaikan sengketa menurut pangngadereng (sistem peradatan) yang ada dan berlaku. ${ }^{16}$

\footnotetext{
11 Rufinus Hotmaulana Hutauruk. (2014). Penanggulangan Kejahatan Korporasi melalui Pendekatan Restoratif; Suatu Terobosan Hukum. Jakarta: Sinar Grafika, hlm. 108-109.

12 Unbanunaek Mimi, et.al. (2014). Diversi dalam Perlindungan Hukum Anak yang Bermasalah Hukum dalam Sistem Peradilan Pidana Anak. $M M H$, 43(2): 305-312.

13 Oheo K. Haris. (2019). Victim's Involvement Model in Children Legal Process Based on Law No. 11/2012 on Children Criminal Justice System. Yuridika. Fakultas Hukum Universitas Airlangga. Journal Unair, 34(1): 109.

14 A. M. Syukri Akub dan Sutiawati. (2018). Keadilan Restoratif (Restorative Justice) Perkembangan, Program serta Prakteknya di Indonesia dan Beberapa Negara. Yogyakarta: Litera (Republik Institut), hlm. 84.

${ }^{15}$ Ibid.

${ }^{16}$ Ibid.
} 
Dewasa ini, sebagian besar negara di dunia modern pada abad ke-21 ini menerapkan "restorative justice" yang lebih menekankan proses hukum pidana pada korban kejahatan, dan memulihkan kerugian yang dideritanya, serta mengharmoniskan kembali hubungan antara pelaku kejahatan dan korban. ${ }^{17}$ Di Indonesia, selain diterapkan oleh masyarakat hukum adat yang masih diakui keberlakuannya dengan berdasar pada Pasal 5 Ayat (3) sub b UndangUndang Darurat Nomor 1 Tahun 1951 yang menetapkan 3 hal, yaitu:

1) Suatu perbuatan yang melanggar hukum yang hidup;

2) Perbuatan pelanggaran tersebut tidak ada bandingannya (tidak dikualifikasikan sebagai delik oleh Kitab Undang-Undang Hukum Pidana/KUHP); dan

3) Perbuatan pelanggaran tersebut masih tetap berlaku untuk kaula-kaula dan orangorang yang bersangkutan.

Walaupun demikian, belum diatur secara jelas dan tegas konsep hukum pidana yang dicita-citakan yang sesuai dengan karakter dan jiwa masyarakat serta budaya Indonesia dalam KUHP. Untuk itu perlu dilakukan upaya pembaharuan hukum pidana sebagai bentuk baru sistem hukum pidana (ius costituendum). Konsep ini sejatinya dan senyatanya merupakan nilai luhur masyarakat Indonesia yang sudah dipraktikkan apabila menyelesaikan masalah atau sengketa yang dialami oleh warga masyarakat.

Diversi pada prinsipnya tidak menghilangkan atau menghapuskan tindak pidana yang telah dilakukan oleh pelaku terhadap korban, melainkan diversi hanyalah salah satu cara atau tindakan yang mengubah atau membelokkan proses pidana yang sedang ditempuh oleh korban dengan menggunakan pendekatan kekeluargaan melalui jalan musyawarah untuk mencapai mufakat. Selain itu, kepentingan untuk mencapai perdamaian dengan tetap memperhatikan dan memulihkan hak-hak korban adalah hal utama yang perlu perhatian.

Sebagaimana dikemukakan Barda Nawawi Arief, bahwa tindakan diversi dapat dilakukan oleh pihak kepolisian, kejaksaan, pihak pengadilan maupun pembina lembaga pemasyarakatan. Penerapan diversi di semua tingkatan ini diharapkan mengurangi efek negatif (negative effect) keterlibatan anak dalam proses peradilan tersebut. Pada dasarnya suatu penegakan hukum akan berhasil dan berjalan maksimal jika tidak terlepas dari tiga pilar yang saling memengaruhi, yakni memenuhi struktur (structure), substansi (substance), dan kultur hukum (legal culture). ${ }^{18}$

Diversi merupakan satu-satunya, yang diakui oleh negara dan diatur dalam norma, suatu bentuk penyimpangan dari sistem peradilan pidana terpadu yang lazim selama ini dijalankan. Proses ini pada prinsipnya tidak menghilangkan hakikat hukum pidana yang bersifat ultimum remedium, akan tetapi semata-mata terkait dengan efektivitas dan efisiensi dari penerapan ultimum remedium itu sendiri.

Masyarakat Indonesia terbiasa dan terlatih menyelesaikan masalah dengan mengedepankan musyawarah untuk mencapai mufakat, perdamaian dan saling menghargai, dan hal itu sebenarnya sama persis dengan konsep yang dianut oleh keadilan restoratif. Keadilan ini menitikberatkan pada keadilan dan kepastian antara retributif dan restitusi, sebab lebih menekankan pada pentingnya peran atau pelibatan korban, pelaku, dan anggota masyarakat, serta mendorong pelaku agar bertanggung jawab kepada korban dengan memulihkan kerugian baik materil maupun imateril, serta emosi korban dengan mengedepankan negosiasi, dialog, dan musyawarah guna mencapai mufakat.

\footnotetext{
${ }^{17}$ Ibid.

${ }^{18}$ Nur Hidayati. (201). Peradilan Pidana Anak dengan Pendekatan Keadilan Restoratif dan Kepentingan Terbaik bagi Anak. Jurnal Pengembangan Humaniora, 13(2): 147.
} 
Diversi akan tercapai apabila ada pemaafan, keihklasan, dan perdamaian dari korban yang didahului dengan permintaan maaf, pengakuan kesalahan serta kesediaan penggantian kerugian oleh pelaku. Satu hal yang perlu diingat berkaitan dengan diversi ini adalah, apabila diversi gagal dilakukan, maka proses penegakan hukum melalui jalur peradilan tetap dilanjutkan dengan menggunakan hukum acara biasa sesuai dengan hukum acara pidana (sistem peradilan pidana).

Hanya saja untuk penyelesaian perkara tindak pidana terhadap harta benda dengan penggunaan konsep diversi sesuai dengan yang diatur dalam perkara anak belumlah memiliki kekuatan yuridis. Konsekuensi yuridis dari tidak diaturnya diversi melalui prinsip keadilan restoratif untuk tindak pidana terhadap harta benda dalam peraturan perundangundangan, mengakibatkan konsep tersebut tidak memiliki kedudukan hukum yang jelas dan tegas dalam sistem peradilan pidana, sehingga berpengaruh pada penerapannya di tingkat penyidikan, penuntutan, maupun di persidangan. Oleh karena tidak diatur, tentunya konsep ini hanya dapat dilaksanakan pada tataran diskresi yang dimiliki oleh penyidik, penuntut umum, maupun hakim, sehingga dalam penerapan dan penegakannya tentula beragam. Masing-masing sesuai dengan penafsirannya dan berpegang pada diskresi yang menjadi kewenangan instansi masing-masing.

Misalnya, pada tahapan penyidikan, penyidik berpedoman pada Surat Edaran Kapolri Nomor 8 Tahun 2018 dalam menjalankan diskresi yang berpedoman pada Undang-Undang Nomor 8 Tahun 1981 tentang Hukum Acara Pidana (KUHAP), Undang-Undang Nomor 2 Tahun 2002 tentang Kepolisian Negara Republik Indonesia, khususnya Pasal 6 Ayat (1) huruf $j$ yang mengatur bahwa penyidik berwenang mengadakan tindakan lain menurut hukum yang bertanggung jawab, serta Peraturan Kapolri Nomor 6 Tahun 2019 tentang Penyidikan Tindak Pidana.

Dalam Surat Edaran termaksud dijelaskan bahwa proses penyelidikan dan penyidikan tindak pidana, merupakan entry point dari suatu penegakan hukum pidana melalui sistem peradilan pidana (criminal justice system) di Indonesia. Oleh karena itu, proses penyelidikan dan penyidikan suatu tindak pidana merupakan kunci utama penentuan dapat tidaknya suatu perkara pidana dilanjutkan ke proses penuntutan dan peradilan pidana. Dengan surat edaran termaksud, Kepolisian Negara Republik Indonesia ingin menjawab perkembangan sistem peradilan pidana dan metode penegakan hukum dalam rangka memberikan dan memenuhi rasa keadilan masyarakat. Polisi Republik Indonesia menyadari bahwa prinsip keadilan restoratif dapat mengurangi over capacity Lembaga Pemasyarakatan, mengurangi tunggakan perkara yang semakin meningkat, jumlah penegak hukum yang tidak seimbang dengan perkembangan perkara, biaya perkara yang tidak mampu mendukung peningkatan perkara dan sebagainya.

Pada prinsipnya surat edaran termaksud bertujuan untuk memenuhi tuntutan rasa keadilan masyarakat dan menjawab perkembangan kebutuhan hukum masyarakat, yang kesemuanya bermuara pada tujuan hukum yaitu keadilan, kemanfaatan, dan kepastian hukum dengan tetap mengedepankan asas peradilan yang cepat, sederhana dan biaya ringan (murah). Dalam surat edaran termaksud juga ditekankan dan menjadi syarat bahwa pelaku harus mengembalikan keseimbangan dengan membebani kewajiban pelaku kejahatan dengan kesadarannya mengakui kesalahan, meminta maaf, dan mengembalikan kerusakan dan kerugian korban seperti semula atau setidaknya menyerupai kondisi semula, yang dapat memenuhi rasa keadilan korban. Selain itu, termaksud juga dijelaskan bahwa penerapan diversi melalui prinsip keadilan restoratif dalam konsep penyelidikan dan penyidikan tindak pidana demi mewujudkan kepentingan umum dan rasa keadilan masyarakat belum memiliki landasan hukum dan belum memiliki pedoman pelaksanaannya. 
Konsep diversi melalui prinsip keadilan restoratif sesungguhnya menginginkan agar pengalihan proses penyelesaian perkara tindak pidana terhadap harta benda yang semula penyelesaiannya dilakukan melalui mekanisme sistem peradilan pidana terpadukonvensional, diubah atau dialihkan dan menjadi penyelesaian perkara di luar peradilan yang berbasis musyawarah dengan melibatkan pelaku, korban, dan juga kedua pihak keluarga, serta aparat penegak hukum selaku mediator yang dapat mengembalikan kondisi ke keadaan semula dan tidak berakhir dipenjaranya si pelaku.

Atas pendekatan diversi melalui penyelesaian keadilan restoratif, korban merasa puas dan diperlakukan dengan adil, karena dilibatkan dalam proses penjatuhan sanksi yang direstorasi, korban memperoleh ganti kerugian sesuai haknya atas kerugian yang dideritanya, serta pelaku sadar dan menyesal terhadap perbuatannya dan terjaga harkatmartabatnya karena tidak dipenjara secara fisik (hukuman badan).

\section{Kesimpulan}

Potensi penggunaan konsep diversi atau dengan jalan musyawarah melalui prinsip keadilan restoratif untuk tindak pidana terhadap harta benda pada hakikatnya dapat diterapkan karena konsep ini telah dipraktikkan oleh masyarakat hukum adat di Indonesia sejak zaman dahulu dan sampai sekarang. Hanya saja, dalam sistem hukum Indonesia atau sistem peradilan pidana belum diatur secara tegas dalam bentuk peraturan perundang-undangan. Penggunaan dan penerapan serta pengaturannya masih dalam tataran diskresi di masingmasing lembaga penegak hukum sesuai dengan aturan internal yang mengikat instansi masing-masing penegak hukum. Mestinya, KUHP sebagai hukum materil dan KUHAP sebagai hukum formil, yang bertujuan memberikan perlindungan hukum kepada korban, pelaku dan aparat penegak hukum, agar tercipta nilai keadilan, kemanfaatan, dan kepastian hukum yang menjunjung tinggi harkat martabat manusia dan kemanusiaan.

\section{Ucapan Terima Kasih}

Penulis mengucapkan terima kasih kepada Tuhan Yang Maha Esa, juga kepada Musakkir, Muhadar dan Haeranah yang telah membimbing saya dalam penyelesaian penelitian ini selama menempuh pendidikan doktoral di Fakultas Hukum Universitas Hasanuddin.

\section{Referensi}

Books with an author:

Akub, A. M. Syukri dan Sutiawati. (2018). Keadilan Restoratif (Restorative Justice) Perkembangan, Program serta Prakteknya di Indonesia dan Beberapa Negara. Yogyakarta: Litera (Republik Institut).

Ali, Achmad dan Heryani, Wiwie. (2013). Menjelajah Kajian Empiris terhadap Hukum. Jakarta: Kencana Prenadamedia Group.

Effendy Marwan. (2014). Teori Hukum dari Perspektif Kebijakan, Perbandingan dan Harmonisasi Hukum Pidana. Jakarta: Referensi Centre Group.

Hutauruk, Rufinus Hotmaulana. (2014). Penanggulangan Kejahatan Korporasi melalui Pendekatan Restoratif; Suatu Terobosan Hukum. Jakarta: Sinar Grafika.

Morris, Edward K. and Braukmann, Curtis J. (1987). Behavioral Approach to Crime and Deliquency: A Handbook of Application, Research and Concepts. New York: Plenum Press.

Wiyono, R. (2016). Sistem Peradilan Pidana Anak di Indonesia. Jakarta: Sinar Grafik. 
Artikel Jurnal:

Anzward, Bruce dan Widodo, Suko. (2020). Kebijakan Penerapan Diversi Dalam Penyelesaian Perkara Tindak Pidana Yang Dilakukan Oleh Anak Melalui Pendekatan Restorative Justice. Jurnal De Facto. 7(1): 38-59.

Haris, Oheo K. (2019). Victim's Involvement Model in Children Legal Process Based on Law No. 11/2012 on Children Criminal Justice System. Yuridika. Fakultas Hukum Universitas Airlangga. Journal Unair, 34(1): 109.

Hidayati, Nur. (2013). Peradilan Pidana Anak dengan Pendekatan Keadilan Restoratif dan Kepentingan Terbaik bagi Anak. Jurnal Pengembangan Humaniora, 13(2): 147.

Mimi, Unbanunaek, et.al. (2014). Diversi dalam Perlindungan Hukum Anak yang Bermasalah Hukum dalam Sistem Peradilan Pidana Anak. MMH, 43(2): 305-312.

Rahman, Muhammad Sabir. (2019). Fines Sanction as a Meeting Form Principles of Agreement Contracts Construction Service. Amsir Law Journal, 1(1): 17. https://doi.org/10.36746/alj.v1i1.18 .

Sari, Novita. (2017). Penerapan Asas Ultimum Remedium dalam Penegakan Hukum Tindak Pidana Penyalahgunaan Narkotika. De Jure, 3(3): 353.

Sidrat, Muhammad, et.al. (2019). Syarat Diversi pada Anak yang Berkonflik dengan Hukum dalam Konsep Pemidanaan Halu Oleo Legal Research. 1(2): 277-290.

\section{Conflict of Interest Statement:}

The author declares that the research was conducted in the absence of any commercial or financial relationships that

could be construed as a potential conflict of interest.

Copyright (C) 2021 ALJ. All rightsreserved. 